\title{
Chemical characteristics (REE, etc.) of Paleozoic and Mesozoic graywackes and sandstones from Central Europe
}

\author{
Karl Hans Wedepohl · Klaus Simon
}

Received: 20 April 2012/ Accepted: 12 May 2012/Published online: 30 May 2012

(C) The Author(s) 2012. This article is published with open access at Springerlink.com

\begin{abstract}
During the Variscan orogeny in Central Europe, partial melting in the lower continental crust formed granitic magmas, which intruded into the upper crust and left compounds of $\mathrm{Ca}$ (plus $\mathrm{Eu}^{2+}$ ), $\mathrm{Mg}$, etc. in the lower crust. From the late Paleozoic decomposition of the tonalitic upper crust, sedimentary graywackes were produced reflecting the composition of this crust. The repeated reworking of the sedimentary cover caused the formation of sands. Sandstones as their products of consolidation contain increasing fractions of quartz and decreasing feldspar from Carboniferous and Triassic to Cretaceous age. A distinct negative $\mathrm{Eu}$ anomaly characterizes the majority of these rocks. The latter is imprinted by the Variscan magmatism. Quartz as used for numerous Medieval wood ash glasses is marked for its Central European origin by a distinct negative Eu anomaly in contrast to many soda glasses produced outside Germany mostly with a small or none $\mathrm{Eu}$ anomaly.
\end{abstract}

Keywords Graywackes - Sandstones · Quartz $\cdot$ Rare earth elements $\cdot$ Medieval glass

We have investigated quartz-bearing coarse-grained sedimentary rocks as originally being formed from tectonic and weathering detritus of the Variscan orogenic mountains in Germany. This orogeny occurred from about 380 to $240 \mathrm{Ma}$ ago and was triggered by heat from the upper mantle. The heat caused partial melting in the lower

Communicated by J. Hoefs.

K. H. Wedepohl $\cdot$ K. Simon $(\bowtie)$

Göttingen, Germany

e-mail: ksimon@gwdg.de continental crust and formed granitic partial melts, which intruded into the upper crust. This orogenic magmatism is connected with an accumulation of potassium and sodium in the granitic melts of the upper crust and of calcium and magnesium in the melting residues of the lower crust. Sandstones formed after the Variscan orogeny contain minor magmatic detritus. The systematic change of their chemical composition with decreasing age will be investigated in this study.

We will use the composition of the $40 \mathrm{~km}$ thick continental Earth's crust as a reference to explain the composition of Paleozoic and Mesozoic coarse-grained sedimentary rocks. A standard profile of the continental crust as taken from a 3,000-km long part of the 4,800-km long traverse of reflection seismic surveys through Europe from the North Cape to Tunesia informs us about the abundance of crustal rocks (Ansorge et al. 1992). This standard profile consists of $7.6 \%$ sedimentary cover, $45 \%$ granites, gabbros, gneisses, mica schists and amphibolites plus $47.7 \%$ lower crustal felsic and mafic granulites. Details about the compositions of the crustal units and concentrations of the chemical elements in the bulk crust were reported by Wedepohl (1995). This bulk crust composition is listed in Table 1. It is close to the composition of tonalites and quartz diorites as common intrusive magmatic rocks.

The abundance of rare earth elements (REE) in our samples will be used as indicators of certain rock forming processes. They were analyzed by Laser Ablation Inductively Coupled Plasma Mass Spectrometry. Under normal conditions in the continental crust, the REE ( $\mathrm{La}, \mathrm{Ce}, \mathrm{Pr}$, $\mathrm{Nd}, \mathrm{Sm}$ to $\mathrm{Lu}$ ) are trivalent. Exceptions are related to certain oxidizing or reducing conditions in the crust. Oxidizing conditions occur in deep-sea sediments with the formation of manganese oxide concretions $\left(\mathrm{MnO}_{2}\right)$. Here, $\mathrm{Ce}^{4+}$ can be formed and be precipitated in $\mathrm{MnO}_{2}$ (Toyoda 
Table 1 Average concentrations of major elements in the Continental Earth's Crust (A), and in a composite of 17 Paleozoic graywackes from Germany (B)

\begin{tabular}{lccc}
\hline & A & B & C \\
& Continental crust & 17 Graywackes Germany & B/A \\
\hline $\mathrm{SiO}_{2}(\%)$ & 61.5 & 67.21 & 1.09 \\
$\mathrm{TiO}_{2}$ & 0.68 & 0.68 & 1.00 \\
$\mathrm{Al}_{2} \mathrm{O}_{3}$ & 15.1 & 11.49 & 0.76 \\
$\mathrm{Fe}_{2} \mathrm{O}_{3}$ & 6.28 & 6.7 & 1.07 \\
$\mathrm{MnO}$ & 0.10 & 0.11 & 1.14 \\
$\mathrm{MgO}$ & 3.7 & 1.4 & 0.38 \\
$\mathrm{CaO}$ & 5.5 & 2.91 & 0.53 \\
$\mathrm{Na}$ & 3.2 & 1.9 & 0.60 \\
$\mathrm{~K}_{2} \mathrm{O}$ & 2.4 & 1.8 & 0.75 \\
$\mathrm{P}_{2} \mathrm{O}_{5}$ & 0.18 & 0.14 & 0.78 \\
$\mathrm{CO}_{2}$ & 0.73 & 2.4 & \\
$\mathrm{H}_{2} \mathrm{O}$ & & 3.13 & \\
$\Sigma$ & 99.4 & 99.9 & \\
\hline
\end{tabular}

Third column: the ratio B/A

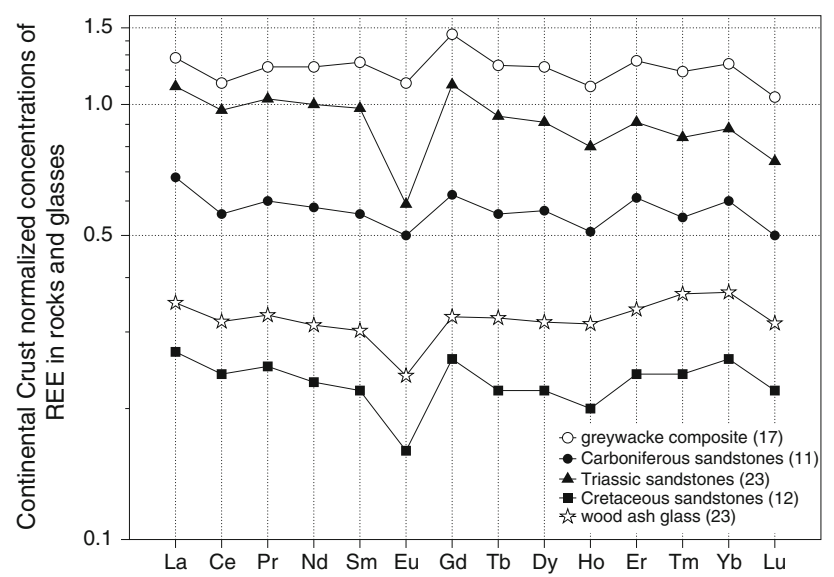

Fig. 1 REE concentrations in rocks normalized to REE concentrations in the Continental Earth's Crust. Rocks are 17 Paleozoic graywackes, 11 Carboniferous sandstones, 23 Triassic sandstones, 12 Cretaceous sandstones and 23 wood ash glasses from Germany

et al. 1990). In seawater being residual from this precipitation, a negative $\mathrm{Ce}$ anomaly will be detected indicating the process of $\mathrm{Ce}^{4+}$ accumulation under oxidizing conditions.

In a former paragraph, we have mentioned the magmatic accumulation of $\mathrm{K}$ and $\mathrm{Na}$ in the upper crust and of $\mathrm{Ca}$ and $\mathrm{Mg}$ in the lower crust. Reducing crustal conditions cause a precipitation of $\mathrm{Eu}^{2+}$ in Ca-rich minerals as plagioclase, etc., in the lower crust, resulting in a positive Eu anomaly in the REE series. The positive anomaly of the lower crust is compensated by a negative anomaly in the upper crust. The negative $\mathrm{Eu}$ anomaly can be observed in the REE spectra of abundant sandstones in Fig. 1.
We have started our present investigation with chemical analyses of a composite of 17 graywackes, which are sandstones containing a large proportion of detrital rock fragments, feldspars, quartz, mica, etc. The samples came from the following areas: Eifel (3), Rhein-Mosel (3), Hessia (4), Westphalia (2), Harz Mountains (4) and Silesia (1). The majority of the sampled graywackes is of Carboniferous and the minority of Devonian age.

In Table 1, we have listed the major element averages of the continental earth's crust (Wedepohl 1995) and of the mentioned composite of 17 graywackes. Because of important similarities in chemical composition between the graywackes (B) and the continental crust (A), the ratios B/A are close to one for the majority of elements. Exceptions with ratios $\mathrm{B} / \mathrm{A}$ close to 0.5 are the elements $\mathrm{Ca}$ and $\mathrm{Mg}$ because they are accumulated in the lower continental crust in plagioclase, etc., as residues of partial melting. The majority of the sampled graywackes with their chemical similarity to abundant crustal rocks indicates their origin from materials formed by the Variscan orogeny. Because the abundance of the REE is similar in graywackes and in the continental crust, the crust-normalized concentrations of $\mathrm{La}, \mathrm{Pr}, \mathrm{Nd}, \mathrm{Sm}, \mathrm{Tb}, \mathrm{Dy}, \mathrm{Er}, \mathrm{Tm}$ and $\mathrm{Yb}$ in Fig. 1 are close to one. They are actually close to 1.3 . We observe a negative Ce anomaly indicating seawater environment, and a positive Eu anomaly in the lower crust from residues of partial melting related to a negative anomaly in the upper crust.

Sandstones of Carboniferous, Triassic and Cretaceous age also have like the graywackes distinct Eu anomalies in memory of the Variscan partial melting events (Fig. 1). We have analyzed composites of 12 Carboniferous, 23 Triassic and 11 Cretaceous sandstones by X-ray fluorescence. The majorities of the Carboniferous samples came from Westphalia, those of Triassic rocks from Hessia, and those of Cretaceous materials from Lower Saxony. Table 2 presents the major element concentrations in composites of graywackes and sandstones. In the sequence from older to younger rocks (except Triassic sandstones), $\mathrm{SiO}_{2}$ increases remarkably. This increase is compensated by a decrease in $\mathrm{Al}_{2} \mathrm{O}_{3}, \mathrm{Fe}_{2} \mathrm{O}_{3}, \mathrm{MgO}, \mathrm{CaO}, \mathrm{Na}_{2} \mathrm{O}$ and $\mathrm{K}_{2} \mathrm{O}$ (again with exceptions in Triassic sandstones). Aluminum concentrations are mainly incorporated in feldspar (and mica). These minerals decrease with distance from the orogeny and the sources of graywackes. The negative $\mathrm{Ce}$ and Eu anomalies in sandstones plotted in Fig. 1 confirm the fact that all these sediments were deposited under seawater and that their original material came at-least partly from the Variscan orogeny. The sequence from older to younger sandstones demonstrates how the original material was repeatedly reworked by weathering, erosion and deposition.

One of the applications of our present investigation is the search for specific properties of quartz used for Medieval glasses in Germany. The 23 investigated wood ash 
Table 2 Average

concentrations of major elements by RFA in composites of 17 Paleozoic graywackes, 12 Carboniferous sandstones, 23

Triassic sandstones and 11

Cretaceous sandstones from Germany, and average concentrations of major elements by microprobe in 23 Medieval wood ash glasses from Germany (Wedepohl et al. 2011)

\begin{tabular}{lccccc}
\hline & $\begin{array}{l}\text { 17 Graywackes } \\
\text { Germany }\end{array}$ & $\begin{array}{l}\text { 11 Carboniferous } \\
\text { sandstones }\end{array}$ & $\begin{array}{l}23 \text { Triassic } \\
\text { sandstones }\end{array}$ & $\begin{array}{l}12 \text { Cretaceous } \\
\text { sandstones }\end{array}$ & $\begin{array}{l}\text { 23 Wood ash } \\
\text { glasses (Medieval) } \\
\text { Germany }\end{array}$ \\
\hline $\mathrm{SiO}_{2}(\%)$ & 67.21 & 80.56 & 80.1 & 91.24 & 50.2 \\
$\mathrm{TiO}_{2}$ & 0.68 & 0.33 & 0.34 & 0.13 & 0.15 \\
$\mathrm{Al}_{2} \mathrm{O}_{3}$ & 11.49 & 8.02 & 7.5 & 1.64 & 2.11 \\
$\mathrm{Fe}_{2} \mathrm{O}_{3}$ & 6.7 & 4.6 & 2.52 & 3.61 & 0.73 \\
$\mathrm{MnO}$ & 0.11 & 0.08 & 0.03 & 0.03 & 1.09 \\
$\mathrm{MgO}$ & 1.4 & 0.57 & 0.55 & 0.02 & 4.35 \\
$\mathrm{CaO}$ & 2.91 & 0.21 & 0.76 & 0.05 & 22.6 \\
$\mathrm{Na}_{2} \mathrm{O}$ & 1.9 & 0.8 & 0.5 & 0.01 & 0.89 \\
$\mathrm{~K}_{2} \mathrm{O}$ & 1.8 & 1.9 & 3.7 & 0.4 & 13.0 \\
$\mathrm{P}_{2} \mathrm{O}_{5}$ & 0.14 & 0.07 & 0.1 & 0.03 & 4.04 \\
$\mathrm{CO}_{2}$ & 2.4 & 1.34 & 1.3 & 1.5 & \\
$\mathrm{H}_{2} \mathrm{O}$ & 3.13 & 1.78 & 2.53 & 0.79 & \\
$\Sigma$ & 99.9 & 98.5 & 97.4 & 98.7 & \\
$\mathrm{Quartz}(\%)$ & & 57 & 66 & 72 & \\
Feldspar $(\%)$ & & 13 & 25 & 5 & \\
\hline & & & & & \\
\hline
\end{tabular}

glasses came from Hoexter (Westphalia), Mainz, Laudengrund (Spessart), Brunshausen (Gandersheim) and Lorsch (Wedepohl et al. 2011). They were made from quartz plus wood ash between the eighth and the fifteenth century in processes specific for that time and area. The major element composition of the 23 Medieval wood ash glasses is listed in Table 2 and their crust-normalized REE composition in Fig. 1. These wood ash glasses contain distinctly less $\mathrm{SiO}_{2}$ but much more $\mathrm{CaO}$ and $\mathrm{K}_{2} \mathrm{O}$ than the sandstones. Besides those 23 materials listed in Table 2, we have observed wood ash glass with an Eu anomaly at Steimcke and Drudewenshusen (both near Göttingen), Paderborn and Sady (CR). Quartz for the glass production is commonly gained from river and sea beds or Tertiary deposits with local accumulation of this mineral. The latter sources apparently contain quartz with similar REE patterns as the sandstones and graywackes from Central Europe including $\mathrm{Eu}$ and $\mathrm{Ce}$ anomalies (Fig. 1). This means that the decomposition of sandstones caused the formation of quartz accumulations. The impact of the Variscan orogeny has finally marked rather large volumes of rocks. The average crust-normalized REE concentrations of the wood ash glasses in Fig. 1 are very similar (except the Eu anomaly). But the size of these concentrations is only a third of that of the continental crust (Wedepohl et al. 2011, Table 2).

In antiquity and the medieval period, two additional glass types beside wood ash glass were in general use in Europe and the Near East, etc.: soda lime glass and soda ash glass. In Fig. 2, we have plotted the average continental crust-normalized REE concentrations in 23 wood ash glasses, 16 soda lime glasses and 20 soda ash glasses as reported by Wedepohl et al. (2011). In this figure, an almost general existence of distinct $\mathrm{Eu}$ anomalies is restricted to the type of wood ash glass. Only two of the wood ash glasses have not such an Eu anomaly. These are from the Spessart Mountains. Six of the investigated Roman soda lime glasses from the production of Hambach west of Cologne (Gaitzsch et al. 2000) have a weak or minor negative and two have a positive Eu anomaly. Two of these soda lime glasses from Bonn, two from Gellep, two from Hambach and one from Augst have no anomaly at all. The third common glass type is soda ash glass that was produced in the period from 900 to $1250 \mathrm{AC}$ exclusively in Islamic areas. Eight samples of beakers with

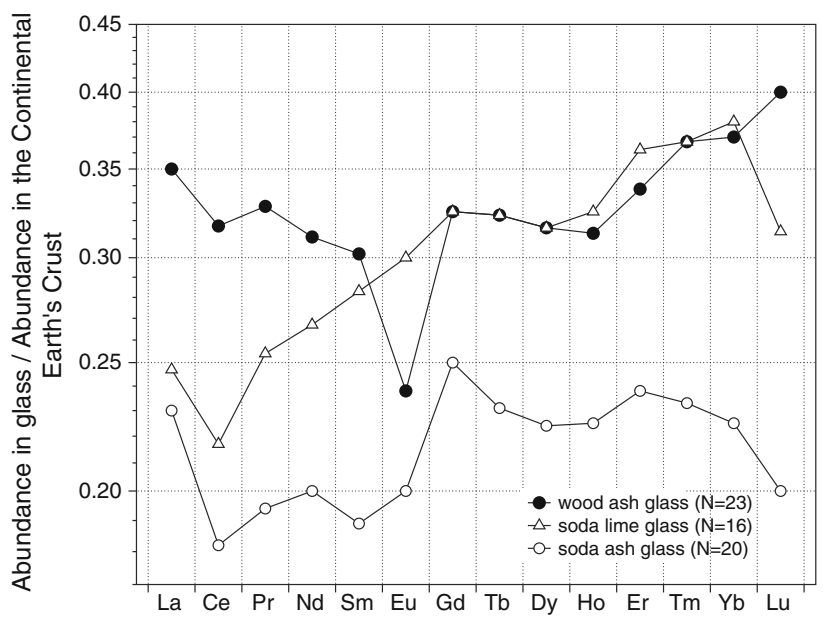

Fig. 2 Average REE concentrations of 23 wood ash glasses, 20 soda ash glasses and 16 soda lime glasses normalized to REE concentrations in the Continental Earth's Crust 
enamel paintings from Venice (excavated at Hoexter) plus three Islamic vessels sampled at Brno (CR) plus four Hedwig beakers with carved decorations (sampled in more than 18 localities in Europe) plus three colored glasses from Qantir in Egypt represent this glass type in our investigation. Only five of the eight beakers from Venice have minor negative Eu anomalies. Two of the three Islamic vessels from Brno also have minor negative $\mathrm{Eu}$ anomalies. The third glass from this locality has a distinct negative Eu signature. Of the 20 representatives of the soda ash type, the four Hedwig beakers exclusively have a distinct negative $\mathrm{Eu}$ anomaly. Conclusions from their chemical investigation locate their production, which is dated to a few decades after $1200 \mathrm{AC}$, in the area of the Levant at the Mediterranean Sea (Wedepohl 2005).

The first part of this publication is restricted to quartz used for wood ash glass in Germany, which is combined with a distinct negative Eu anomaly introduced through Late Paleozoic magmatism in the upper crust. Considering a much larger geographic area of glass production by the inclusion of soda ash and soda lime glass outside Germany, the negative $\mathrm{Eu}$ anomalies decrease to a minor size. The latter case seems to be normal for the upper crust in general.

\section{Conclusions}

The repeated reworking of coarse-grained quartz-bearing materials from Variscan rocks and their deposition in the Carboniferous to Cretaceous sea formed sands and sandstones with increasing proportions of quartz. The youngest deposits still reflect imprints of the Variscan orogeny as an Eu anomaly. Wood ash glass produced in Medieval Germany carries distinct negative Eu anomalies from the same source as in sandstones. Soda glass from large areas outside Germany has only small or none positive or negative $\mathrm{Eu}$ signatures.

Open Access This article is distributed under the terms of the Creative Commons Attribution License which permits any use, distribution, and reproduction in any medium, provided the original author(s) and the source are credited.

\section{References}

Ansorge J, Blundell D, Mueller S (1992) Europe's lithosphereseismic structure. In: Blundell D et al (eds) A continent revealed. The European Geotraverse. Cambridge University Press, Cambridge, pp 33-69

Gaitzsch W, Follmann-Schulz A-B, Wedepohl KH, Hartmann G, Tegtmeier U (2000) Spätrömische Glashütten im Hambacher Forst-Produktionsort der ECVA-Fasskrüge. Bonner Jahrbücher Band 200:83-241

Toyoda K, Nakamura Y, Masuda A (1990) Rare earth elements of Pacific pelagic sediments. Geochim Cosmochim Acta 54:10931103

Wedepohl KH (1995) The composition of the continental crust. Geochim Cosmochim Acta 59:1217-1232

Wedepohl KH (2005) Die Gruppe der Hedwigsbecher. Nachrichten der Akademie der Wissenschaften zu Göttingen, II. Mathematisch-Physikalische Klasse Nr. 1. Vandenhoeck \& Ruprecht, Göttingen

Wedepohl KH, Simon K, Kronz A (2011) Data on 61 chemical elements for the characterization of three major glass compositions in late antiquity and the Middle Ages. Archaeometry 53-1:81-102 